\title{
Avanços e retrocessos da educação em Angola
}

\author{
ERMELINDA LIBERATO \\ Universidade Agostinho Neto, Luanda, Angola
}

RESUMO

A educação em Angola tem atravessado momentos pautados por avanços e retrocessos de política educativa que condicionaram sua evolução positiva bem como sua afirmação no cenário internacional e até mesmo regional. Pretendemos assim, por meio de pesquisa bibliográfica e consulta de arquivos, analisar esse percurso, realçando as medidas mais emblemáticas, com especial ênfase ao período de intensificação da política colonial portuguesa, o período pós-independência, e terminando com o período de consolidação da paz. Esta análise extensiva permite-nos entender por que o sistema educativo daquele país enfrenta ainda diversas dificuldades que limitam não só seu desempenho, mas, sobretudo, sua valorização.

PALAVRAS-CHAVE

educação; Igrejas; Angola. 


\section{EDUCATION IN ANGOLA: PROGRESS AND RETARDATION}

\section{ABSTRACT}

The education in Angola has had moments, guided by advances and setbacks in it's education policy, that lead to positive developments as well as it's affirmation in the international and even regional context. We therefore want, via a bibliographic and archive search, to consider this route, highlighting the most emblematic measures, with special emphasis on the period of intensification of Portuguese colonial policy, the post-independence period and ending with the period of consolidation of peace. This extensive analysis enabled us to understand why the Angolan education system still faces many difficulties that limit not only their performance but, above all their overall value.

KEYWORDS

education; Church; Angola.

\section{AVANCES Y RETROCESOS DE LA EDUCACIÓN EN ANGOLA}

\section{RESUMEN}

La educación en Angola ha atravesado momentos pautados por avances y retrocesos de su política educativa que condicionaron su evolución positiva y su afirmación en el escenario regional e, incluso, internacional. Pretendemos así, mediante investigación bibliográfica y consulta de archivos, analizar dicho proceso, realzando las medidas más emblemáticas, con especial énfasis en el período de intensificación de la política colonial portuguesa, el período posterior a la independencia y terminando con el período de consolidación de la paz. Este extenso análisis nos permite comprender por qué el sistema educativo de ese país aún enfrenta diversas dificultades que limitan su rendimiento y, principalmente,su valorización. 


\section{INTRODUÇÃO}

Numa altura em que a educação vem assumindo cada vez mais um papel de destaque nas políticas de cooperação (PNUD, 2010) e em que o reconhecimento da sua importância no processo de desenvolvimento está mais que comprovado (Delors, 1996; Morin, 2002), propomo-nos fazer um balanço sobre o atual estado da educação em Angola. Para o efeito, fazemos uma revisão das políticas educativas implementadas em Angola a partir da segunda metade do século XIX até à atualidade. Esse recuo temporal justifica-se para melhor se perceber o atual panorama da educação em Angola, pois, como afirma Borges Graça (2005, p. 47), "só é possível compreender plenamente uma situação num dado presente se neste for integrado quer o passado quer o futuro". Assim, apresentamos três contextos históricos e sociais diferentes, porém interligados: período colonial, período pós-independência (Primeira República) e Segunda República.

Começamos por apresentar a política educativa colonial, com destaque para a segunda metade do século XIX, período de intensificação da colonização daquele território. Seguem-se as alterações introduzidas no período da Primeira República (portuguesa), sem deixar de referir as políticas educativas do Estado Novo. Far-se-á ainda referência ao contributo das igrejas (católica e protestante) na formação de angolanos (não brancos).

De seguida, apresentamos uma análise das principais alterações em termos das políticas educativas, introduzidas depois da independência, o período de implantação da República Popular de Angola (RPA), as alterações depois de 1991, bem como a reforma aprovada em 2001, dando seguimento às orientações emanadas da Conferência de Jomtien (Tailândia) (1961) e do Fórum Mundial Sobre Educação de Dacar (2000).

\section{A POLÍTICA (COLONIAL) EDUCATIVA PORTUGUESA}

O interesse político e económico de Portugal pelos territórios africanos, por si colonizados, concretizou-se sobretudo a partir do século XIX, mais concretamente depois da independência política do Brasil, em 1825. Perdido que estava o segundo Império e habituados, sob o ponto de vista económico e institucional, à existência de um império sul-atlântico, Portugal começa a elaborar os primeiros projetos para a instalação de seu império no continente africano, idealizando, assim, o seu terceiro Império (Alexandre, 1979, 2000; Telo, 1994).

Até essa data, a presença portuguesa no território angolano, em número pouco significativo, encontrava-se limitada às zonas costeiras (em particular a Luanda e Benguela). Em relação ao interior, apenas os postos comerciais e militares registavam a presença de população europeia, situação que condicionou a criação de laços no relacionamento entre Portugal e esta sua colónia que unissem os respetivos setores económicos dos dois territórios, assentando a economia de Angola apenas no fornecimento de mão de obra para as plantações de cana-de-açúcar e, mais tarde, nos séculos XVII e XVIII, para as minas do Brasil (Martins, 1953, p. 9). Em contrapartida, Angola foi considerada uma terra de degredo, para onde 
foram enviados os condenados ou os excluídos sociais, não atraindo, por essa razão, a fixação das famílias provenientes da metrópole (Dias, 1984), condicionando deste modo o investimento no ensino formal.

Para inverter essa situação e no intuito de desenvolver o território e atrair a imigração de famílias portuguesas, tornou-se essencial a criação de um sistema de ensino naquele território. Assim, apenas em 1845 foi instituída em Angola uma estrutura oficial do ensino, pelo decreto de 14 de agosto de 1845, criado por Joaquim José Falcão, ministro do Estado, da Marinha e do Ultramar, e assinado pela rainha D. Maria II. Falcão criou algumas escolas, tal como a Escola Principal de Instrução Primária, e constituiu um Conselho Inspetor de Instrução Pública. Esse primeiro passo, apesar de importante, não foi contudo suficiente, uma vez que as populações não estavam motivadas nem tão pouco preparadas para a frequência escolar, sendo por isso necessário dar tempo a que as medidas se consolidassem. Para dar novo impulso à educação, dez anos depois, Sá da Bandeira, ministro da Guerra e dos Negócios Estrangeiros, subscreveu uma portaria régia (datada de 19 de novembro de 1856) que determinou que "os filhos dos régulos, sobas e outros potentados indígenas deveriam ser educados em Luanda, sob a orientação e vigilância das autoridades portuguesas, a expensas do Estado" (Santos, 1970, p. 134). Aprendendo a língua e a cultura portuguesa, eles iriam transmitir, posteriormente, os conhecimentos adquiridos ao seu povo, consolidando assim o "saber português".

A partir de então, as iniciativas para se criar em Angola um sistema de ensino não cessaram, tendo para o efeito sido tomadas várias medidas. Assim, em 30 de novembro de 1869 foi publicado, por Luís Augusto Rebelo da Silva, um decreto cuja inovação consistia na "articulação da escola principal, não como grau superior de ensino primário, mas como o primeiro grau do ensino secundário" (Ávila de Azevedo, 1958, p. 126).

A política portuguesa em relação às possessões africanas só começou a registar alterações significativas a partir do último quartel do século XIX, quando a Conferência de Berlim "repartiu" a África entre as potências europeias e delimitou as fronteiras de cada país, e o Ultimatum britânico deitou por terra o "sonho cor-de-rosa" português de unir os territórios de Angola e de Moçambique (com a falência do denominado "Mapa Cor-de-Rosa"). Esses dois acontecimentos deram lugar a substanciais mudanças de atitude, emergindo, desse modo, um novo sentimento patriótico e abrindo espaço à formação de uma nova ideologia, essencialmente nacionalista, mas igualmente racista, que influenciou os discursos políticos e os círculos intelectuais de então e marcou toda a política colonial portuguesa para as colónias africanas, até a segunda metade do século XX.

De acordo com os defensores dessa ideologia, que tem em José Pedro de Oliveira Martins (1845-1894) o seu principal representante, o homem branco português, tinha como missão "civilizar" os negros, considerados "seres biologicamente inferiores", cuja única utilidade seria o trabalho, pois seu estado "antropologicamente inferior, não raro próximo do antropoide e bem pouco digno do nome de homem" (Martins, 1953, p. 254), com capacidades limitadas de aprendizagem, não the permitia outra atividade, pelo que seria absurdo pensar na sua educação, pois "toda a história provava que só pela força se educam povos bárbaros"(idem, p. 261). 
Posição partilhada por António Enes (1946, p. 33), em 1899, que, no seu relatório sobre o trabalho indígena, ressaltou a relação civilizado/primitivo e caraterizou os negros como "vadios", "ociosos", "ignorantes e irresponsáveis", seres inferiores para quem nem a "instrução [seria] meio essencial de aperfeiçoamento". Por isso só com o trabalho e sob vigilância dos "filhos apurados das raças policiadas" se conseguiria "aperfeiçoar a personalidade do africano bronco" (idem, p. 26).

Em 1910, com a implantação da República, a política colonial para os territórios africanos registou novamente alterações, ${ }^{1}$ oscilando entre a:

Continuação dos modelos liberais, formalmente mantidos na constituição de 1911 e no discurso dos responsáveis metropolitanos, e o assumido pragmatismo dos administradores coloniais que impuseram nos territórios africanos uma mais vincada soberania branca e uma mais sistemática exploração dos recursos. (Rodrigues, 2003, p. 23-24)

Depois de uma primeira fase de "conquista" do território, a ideologia colonial portuguesa acentuou sua base nacionalista. $\mathrm{O}$ africano, apesar de ainda considerado antropologicamente inferior, já era visto como “civilizável”. Nesse período (1910-1926), a política colonial para Angola ficou marcada pela governação emblemática de Norton de Matos, primeiro como governador-geral entre 1912-1914 e, mais tarde, como alto-comissário, entre 1921-1924 (Gonçalves, 2003; Léonard, 2000).

Norton de Matos destacou-se pela intenção de reformar, autonomizar e descentralizar política e economicamente as colónias, projeto que lhe valeu muitas críticas na metrópole (Leal, 1924). Dando continuidade às teses do "darwinismo social", defendeu a "fixação da raça portuguesa em Angola" de modo que se pudesse "estabelecer um tipo superior de civilização" (Matos, 1926, p. 30), uma vez que os africanos mais não eram do que "simples instrumentos de trabalho" (idem, p. 232). Mostrou-se contrário também à mistura de raças, defendendo que "conservaremos, para bem de uns e de outros, a mais escrupulosa separação" (idem, p. 233). Para o efeito, classificou a população angolana em cinco categorias:

i) os selvagens com os seus costumes próprios, ii) os europeus que se embruteceram em contato com os nativos e adotaram costumes e hábitos correspondentes, iii) os nativos assimilados mas sem ocupação útil, os conhecidos "calcinha", iv) os nativos que adotaram costumes e hábitos civilizados, integrando-se perfeitamente na vida social, v) os europeus que formavam o grupo orientador por excelência, promotores da elevação cultural, económica e social da província. (Santos, 1970, p. 249)

No campo educativo, Norton de Matos defendeu a instrução em Angola como meio de civilização dos angolanos, utilizando para o efeito a língua portuguesa, ou seja, ficando proibido o uso de qualquer língua africana naquele território.

1 Leis n. 277 e n. 278, de 15 de agosto de 1914, que institucionalizaram a Administração Civil e Financeira das Províncias Ultramarinas. 
Defendeu, de igual modo, a separação da educação ministrada aos africanos daquela ministrada aos portugueses. Para o indígena, a instrução literária limitava-se somente a:

falar, ler e escrever o português, as quatro operações aritméticas e o conhecimento da moeda corrente de Angola. Simples palestras sobre higiene das pessoas e das habitações, contra os vícios e práticas nocivas, usos e costumes nefastos das vidas dos indígenas sobre a história de Portugal e os benefícios da civilização portuguesa adequadas às idades e ao desenvolvimento intelectual dos ouvintes, serão frequentemente feitas. (Matos, 1926, p. 250-251)

Prevalecia a instrução técnica e profissional em detrimento da instrução literária e humanística. Para tal, foram criadas as escolas-oficinas para as raparigas e para os rapazes, em separado. Para as raparigas, a instrução ministrada consistia no:

Ensino teórico e prático da instrução literária em grau primário elementar; ensino de costura e trabalhos domésticos e de quaisquer profissões compatíveis com o seu sexo; educação moral e cultura física. (idem, p. 103)

De modo semelhante, para os rapazes, a instrução consistia essencialmente em:

Ensino teórico e prático da instrução literária, em grau primário elementar; ensino primário técnico de artes e ofícios ${ }^{2}$ e educação moral e cultura física. (idem, ibidem)

Essa política educacional teve continuidade nos anos que se seguiram à presença de Norton de Matos em Angola. Acentuaram-se, e generalizaram-se, os discursos sobre a superioridade da raça europeia, com destaque para Armindo Monteiro, ministro das Colónias entre 1931-1935, que justificava a presença de portugueses em Angola com a missão civilizadora de "tratar e cuidar do negro". ${ }^{3}$ Os africanos transformaram-se, assim, em súbditos, e não em cidadãos, pois, tendo muitos deveres, usufruíam de poucos ou nenhuns direitos.

O período que decorreu entre 1926 e 1930, caraterizado pela ditadura militar, serviu de preparação para a implantação do Estado Novo, um regime político autoritário, policial (Polícia Internacional e de Defesa do Estado - PIDE - e Direção Geral de Segurança-DGS), corporativista, ${ }^{4}$ totalitarista, com forte intervenção do

2 Carpintaria, marcenaria, pedreiro, alfaiataria, sapateiro, ferreiro, serralheiro, entre outros ofícios.

3 "Colonizar é essencialmente tratar do negro. O Branco, por agora ao menos, está a ser o dirigente, o técnico, o responsável. Nos trópicos faria triste figura trabalhar com o seu braço, ao lado do nativo. Esta é a grande força de produção, o abundante e dócil elemento de consumo que África oferece" (Monteiro, 1935, p. 43).

4 O corporativismo defende que "a sociedade se compõe não de classes antagónicas, mas de grupos harmónicos, divididos verticalmente segundo as respetivas funções na comunidade" (Mónica, 1978, p. 3). 
Estado em todos os setores e regulado por uma moral nacionalista cristã. Liderado por António de Oliveira Salazar, presidente do Conselho, um líder que aparecia como "o verdadeiro herdeiro dos ideais contrarrevolucionários clássicos e iria construir um Estado que negava no essencial a tradição de liberalismo dos séculos XIX e XX" (Mónica, 1978, p. 86).

No que respeita aos territórios ultramarinos, a grande novidade é o "controlo efetivo de Angola e Moçambique, a reorganização da respetiva administração em moldes civis e a instalação do aparelho de Estado colonial moderno" (Castelo, 2007, p. 61). A política colonial que então se promoveu assentava sobretudo na diferença entre o "nós", raça portuguesa, e os "outros", indígenas, separação legalizada pela nova política do indigenato (1926) e pelo Ato Colonial (1930). A ideologia da raça acentuou, assim, a separação entre os brancos, oriundos da metrópole; os brancos naturais de Angola; os africanos, civilizados e não civilizados (indígenas). Angola não seria mais a terra de deportados ou de selvagens, pois a raça civilizada, munida de instrução, iria conseguir levar a cabo sua missão de civilizar os africanos, por meio de um processo de assimilação, que consistia em:

Saber ler, escrever e falar português, ter meios suficientes para sustentar a família, ter bom comportamento, ter a necessária educação e hábitos individuais e sociais, de modo a poder viver sob a lei pública e privada de Portugal e fazer um requerimento à autoridade administrativa da área que o levará ao governador do distrito para ser aprovado. (Mazula, 1995, p. 97)

A figura do "assimilado" foi, desse modo, concebida para ser um tipo intermédio entre os brancos e os indígenas. $\mathrm{Na}$ realidade, o processo de assimilação consistia na "eficaz barreira linguística e cultural à ascensão social da maioria da população negra,já que os brancos eram automaticamente considerados 'civilizados"” (Neto, 1997, p. 342).

Nos primeiros anos do Estado Novo, a política educativa na metrópole conheceu muitas alterações, algumas das quais resultaram mesmo em retrocessos. ${ }^{6}$ A escola foi transformada em veículo de transmissão da ideologia salazarista, pelo que, "saber ler, escrever e contar bastava à maioria dos portugueses" (Mónica, 1973, p. 487), impedindo assim o desenvolvimento de uma massa crítica que poderia evoluir para uma oposição ao regime. Assim, a escolaridade obrigatória foi fixada

5 Decreto n. 18.570, de 8 de julho de 1930. Estabelece o quadro institucional das colónias, põe fim ao regime descentralizado e de curta autonomia dos territórios coloniais ao reforçar a fiscalização, priorizar o capital nacional e implantar uma forte complementaridade comercial com a metrópole (Alexandre, 1979; Castelo, 2007; Pimenta, 2008).

6 A política educacional dos republicanos centrou-se na melhoria da qualificação do pessoal docente. A escolaridade primária foi alargada para cinco anos, findos os quais os alunos podiam ingressar nas escolas primárias superiores (três anos). Contudo, a glória da República consistiu na melhoria efetiva das condições de ensino (Mónica, 1978, p. 483-484). 
primeiro em quatro anos e, pouco depois, em três anos, sendo que, aqueles que fossem reprovados mais de três vezes seriam obrigados a abandonar a escola.

No que toca à política educativa em África, as medidas tomadas pelo Estado Novo apontavam igualmente para o enaltecimento dos feitos portugueses e para tentativas de integração dos africanos na cultura portuguesa. Desse modo, foram elaboradas duas políticas educativas: a educação oficial, destinada aos filhos dos colonos, e a educação especialmente destinada aos indígenas.

A educação do colono tinha suas bases na política educativa em vigor na metrópole, sendo, contudo, imbuída pela mensagem dos colonizadores, enquanto agentes da civilização. Em relação à educação dos indígenas, esta tinha como objetivo a "evolução das sociedades arcaicas/atrasadas no sentido do progresso civilizacional"(Paulo, 2000, p. 306), continuando sob a responsabilidade das missões católicas. Contudo, as tímidas melhorias registadas não alteraram o baixo grau de instrução dos angolanos, uma vez que a "maioria dos africanos era excluída através de processos fortemente seletivos, do acesso a qualquer grau de instrução acima do nível primário" (Guimarães, 2006, p. 103), acabando por ser orientada para o ensino técnico profissional, no qual a mão de obra era cada vez mais procurada. Daí que, em "1940, apenas 1.012 africanos (angolanos) [soubessem] ler e escrever português, o que representava menos de 0,03 por cento de todos os africanos da colónia" (Bender, 2009, p. 352).

A criação da Organização das Nações Unidas (ONU) em 1945 (após a Segunda Guerra Mundial) veio aumentar a vigilância internacional sobre os regimes políticos e respetivas formas de governação. A criação da Carta das Nações Unidas, em que se consagrou o princípio da autodeterminação dos povos colonizados e posteriormente a criação da Declaração Universal dos Direitos do Homem (1948), que reafirmou a autodeterminação como um direito fundamental, levaram à emergência do processo de descolonização dos territórios ocupados pelas potências europeias. Portugal procedeu, na sequência desses consensos internacionais, a algumas alterações da sua política colonial desde logo em termos das designações adotadas.

Assim, em 1953 “o império dá lugar às províncias ultramarinas (Lei Orgânica do Ultramar Português)" (Neto, 1997, p. 346), argumentando que Portugal seria um só país, não tendo por isso de prestar contas do que se passava no interior do

\section{Quadro 1 - Europeus em Angola}

(1900-1960)

\begin{tabular}{|r|r|}
\hline Ano & Europeus em Angola \\
\hline 1900 & 9.177 \\
\hline 1920 & 20.000 \\
\hline 1940 & 44.083 \\
\hline 1950 & 78.000 \\
\hline 1955 & 110.000 \\
\hline 1960 & 172.000 \\
\hline
\end{tabular}

Fonte: Pélissier e Wheeler (2011, p. 205). Elaboração da autora. 
seu território. Aumentaram igualmente os incentivos à emigração e à fixação de portugueses no ultramar.

Como podemos verificar pelo Quadro 1, em 1960 encontravam-se em Angola 172 mil europeus contra 9.177 no início do século. No espaço de apenas dez anos, entre 1950 e 1960, esse número mais que duplicou com a entrada em Angola de 94 mil europeus, e o maior número ocorreu depois de 1955.

Em resultado dessas pressões internacionais, ${ }^{7}$ em 1961 o Estatuto dos Indígenas foi abolido com as reformas introduzidas por Adriano Moreira, quando ministro do Ultramar, desaparecendo assim, pelo menos legalmente, a distinção entre indígenas e portugueses e sendo estabelecido o princípio da igualdade de direitos e deveres para africanos e europeus.

Em relação à política educativa, o governo de Angola assumiu, a partir de 1961, a responsabilidade direta pela educação da população em geral. Assistiu-se ao desenvolvimento da rede escolar primária nos centros urbanos e em certas áreas rurais com a aprovação do Levar a escola à sanzala: Plano de Ensino primário rural em Angola 1961-62, da autoria do então secretário provincial da educação, Amadeu Castilho Soares. Esse plano visava à expansão da escolarização e do ensino da língua portuguesa em todo o território angolano, sobretudo fora dos centros urbanos, onde o acesso estava limitado, servindo de base para a uniformização institucional e curricular do sistema educativo que culminou com a Reforma do Ensino Primário Elementar nas Províncias Ultramarinas, realizada em $1964 .{ }^{8}$ Esta instituíu o ensino primário como obrigatório e "gratuito para as crianças dos 6 aos 12 anos" (Soares, 2002, p. 13), nos seguintes termos:

O ensino primário é constituído por quatro classes precedidas de uma classe preparatória e formando um só ciclo, terminando com a aprovação do exame da quarta classe. A classe preparatória visa a prática do uso oral corrente da língua nacional e atividades preparatórias da recetividade para o ensino escolarizado. (Agência..., 1966, p. 43)

Foram igualmente criadas, por decreto ministerial e por proposta do governo-geral de Angola, escolas do magistério primário ${ }^{9}$ para a formação de professores, bem como para a formação de monitores e regentes escolares, de modo que, em 1965, "cada um dos 14 distritos administrativos tinha cursos para monitores, sendo frequentados por 2.413 alunos" (Henderson, 1990, p. 340).

No entanto, essa expansão quantitativa não teve tradução equiparável, em termos qualitativos, uma vez que os objetivos fundamentais dessa política educativa assentavam na adoção dos valores portugueses, sendo a língua portuguesa $o$ veículo transmissor de conhecimento. Esse era, porém, igualmente o maior entrave

7 No dia 20 de abril de 1961, a ONU aprovou a resolução n. 1.603 (XV), na qual condenava a política colonial portuguesa, criando igualmente um subcomité para elaborar um relatório sobre a situação em Angola.

8 Decreto n. 45.908, de 10 de setembro de 1964.

9 Decreto n. 44.240, de 17 de março de 1962. 
à ampliação e adequação à política educativa à realidade angolana. Assistimos, assim, a uma continuidade da política educativa diferenciadora entre os direitos e os deveres de cada um dos grupos raciais e consequentemente das classes sociais, uma vez que os mais favorecidos tinham condições de continuarem os estudos, ao passo que os menos favorecidos continuavam em situação de desvantagem (Neto, 1997).

\section{A CRIAÇÃO DOS ESTUDOS GERAIS UNIVERSITÁRIOS}

Até ao início da década de 1960, Angola não dispunha de nenhuma instituição de ensino superior no seu território. Para a frequência desse nível de ensino, os estudantes tinham de se deslocar a Portugal. No entanto, apesar de serem atribuídas bolsas de estudo para a frequência do ensino superior na metrópole, o fato é que esse acesso estava vedado à maioria dos angolanos. Os custos incomportáveis relacionados com a deslocação e manutenção desses estudantes na metrópole afastavam a maioria dos candidatos ao ensino universitário, daí que "entre 1833 e 1857 estudassem na Europa apenas 19 estudantes angolanos" (Santos, 1970, p. 117), um número muito reduzido para as reais necessidades do país.

Há muito que os colonos, e a elite mestiça e negra assimilada, pediam a criação de uma instituição de ensino superior em Angola, mas a metrópole nunca acatou essa reivindicação (Pimenta, 2008), preferindo manter o sistema de bolsas de estudo, condicionando assim a ascensão social e as aspirações dos angolanos a cargos mais elevados na administração colonial. ${ }^{10}$ Atendendo às exigências da população, $o$ governador-geral Venâncio Deslandes apresentou ao ministro do Ultramar, Adriano Moreira, o primeiro projeto de criação do ensino superior em Angola, que recebeu a designação de Escola Superior Politécnica de Angola (ESPA). Essa discussão foi no entanto adiada por Moreira ter considerado que a decisão estava "dependente de outros condicionalismos institucionais" (Soares, 2004, p. 3), ou seja, da decisão do poder central sediado em Lisboa.

Contrariando as ordens da metrópole, no dia 21 de abril de 1962, Deslandes convocou uma sessão extraordinária do Conselho Legislativo de Angola, que aprovou o projeto de diploma legislativo n. 3.235, o qual instituía os centros de estudos universitários. Estes funcionariam junto ao Instituto de Investigação Científica de Angola (IICA), ao Instituto de Investigação Médica de Angola (IIMA) e ao Laboratório de Engenharia de Angola (LEA). Os centros de estudos universitários visavam à formação de "professores do ensino secundário e de técnicos das especialidades mais necessárias à promoção do bem-estar e assistência sanitária da população, das atividades da construção, produção, distribuição e transporte" (Soares, 2004, p. 7). Para o efeito foram criados cinco desses centros distribuídos por Luanda (arte e medicina), Lubango (educação) e Huambo (agronomia e veterinária). ${ }^{11}$

$10 \mathrm{Na}$ década de 1950, foi criado o Movimento Pró-Universidade de Angola, promovido pelos colonos a partir do Lubango, que tinha como principal reivindicação a criação do ensino superior em Angola (Pimenta, 2008, p. 290).

11 Portarias n. 12.196 e 12.201, de 21 de abril de 1962. 
A 23 de julho de 1962, o ministério do Ultramar, pelo decreto n. 44.472, anulou o diploma legislativo n. 3.235, bem como as portarias n.12.196 e n.12.201, declarando a criação dos centros de estudos universitários inconstitucional. Essa decisão não foi bem aceite em Angola, nomeadamente pelos colonos, que, de ânimos exaltados e apoiando o governador-geral, chegaram a reclamar a independência de Angola como resposta à desautorização de uma decisão aprovada em Conselho Legislativo, um órgão do governo de Angola. Diante da gravidade da situação e aos contornos que esta poderia tomar, Adriano Moreira procurou "despertar da letargia em que se encontravam adormecidas as instituições e as pessoas" (Soares, 2004, p. 10) na metrópole, conseguindo finalmente a aprovação para a criação de universidades no ultramar. A 21 de agosto de 1962, foram então criados os Estudos Gerais Universitários de Angola e Moçambique, integrados à Universidade Portuguesa, que ministraria cursos correspondentes às áreas mais carenciadas de pessoal qualificado, com equivalência em todo o território português.

Os Estudos Gerais começaram a funcionar em 1963, disponibilizando os cursos de "medicina, engenharia, veterinária, agronomia, silvicultura e ciências pedagógicas" (Santos, 1970, p. 289). Sua inauguração contou com a presença do então presidente da República portuguesa, Américo Tomás, que se encontrava de visita a Angola. ${ }^{12}$ Os Estudos Gerais, também criados em Moçambique, marcaram assim uma mudança significativa na política educativa nas colónias. "Em 1963 estas faculdades eram frequentadas por 314 alunos, e em 1966 já havia cerca de 600, sendo a grande maioria branca" (Henderson, 1990, p. 342).

Em 1968 os Estudos Gerais receberam a designação de Universidade de Luanda, por meio da promulgação do decreto-lei n. 48.790, de 11 de dezembro, emanado do governo central em Lisboa. No ano letivo de 1973/1974, a Universidade de Luanda albergava já "2.354 alunos, ensinados por um corpo docente de 274 elementos" (Gulbenkian, 1987, p. 16). Somente em 1975, meses antes da proclamação da independência, a Universidade de Luanda foi desdobrada, e os polos universitários ganharam autonomia, passando a designar-se Universidade de Huambo e Universidade de Lubango.

\section{O PAPEL DAS IGREJAS (CATÓLICA E PROTESTANTE) NA FORMAÇÃO DOS ANGOLANOS}

Desde o início da presença europeia em África que as igrejas católica e protestante têm acompanhado esse empreendimento, ficando responsáveis não somente pela evangelização dos nativos, como também pela sua educação. No primeiro caso (missões católicas), as primeiras a fundar uma escola naquele território no início do século XVII foram as missões jesuítas, ficando assim encarregues do setor educativo (Santos, 1970). No segundo caso (missões protestantes), sua importância advém

12 A Revista Mensal de Doutrina, Estudo e Propaganda Instrutiva dedicou um número especial à visita do presidente Américo Tomás a Angola. 
do fato de terem proporcionado aos angolanos (sobretudo negros) bolsas de estudo para realização da formação superior (Henderson, 1990).

De destacar o papel desempenhado pelos jesuítas, que se dedicaram à pregação da fé católica e ao trabalho educativo ao aperceberem-se que não seria possível converter os novos povos sem que estes soubessem ler e escrever. De fato, a ação educativa só tomou "corpo com o estabelecimento dos jesuítas em Angola" (Dias, 1934, p. 5), os quais, honrando sua exigente e rigorosa formação, assumiram essa responsabilidade, fundando seu primeiro estabelecimento de ensino (e durante grande parte do século XVII o único) em 1605, para onde acorriam "crianças indígenas de toda a parte do Congo e de Angola” (Ávila de Azevedo, 1945, p. 8).

$\mathrm{O}$ fato de terem sido os primeiros a manter uma escola de primeiras letras e talvez até outras de estudos mais adiantados durante todo o século XVII (Santos, 1970, p. 35) fez aumentar a credibilidade e influência dos jesuítas, tornando-os responsáveis pela educação dos "africanos, mulatos e portugueses" (Duffy, 1961, p.118). No entanto, sua expulsão de todo o território do reino de Portugal, decretada em 1760 pelo Marquês de Pombal, levou ao desmantelamento e extinção de todo o sistema de ensino jesuítico, bem como ao encerramento das escolas e confisco dos seus bens, resultando essa ação num retrocesso da educação não branca daquele território.

A par das atividades dos jesuítas, outras ordens estabeleceram-se em diversas regiões, embora não alcançassem a mesma notoriedade: os beneditinos, os franciscanos, os dominicanos, os capuchinhos e os carmelitas.

A concentração da atenção da metrópole em terras do Brasil, a que já aludimos, bem como a expulsão dos jesuítas, contribuíram para o enfraquecimento, a partir do início do século XIX, do número de missionários na colónia de Angola, chegando a ser apenas cinco em 1853, uma diminuição de 34 missionários se tomarmos os 39 do início do século. Essa situação começou a registar alterações, aumentando a partir da segunda metade do século XIX, quando se registou um "esforço de missionação das igrejas cristãs" (Rodrigues, 2003, p. 175), coincidindo com a intensificação da política colonial portuguesa, assim como com a chegada e permanência das missões protestantes.

No período que se seguiu à implantação da República, a "evangelização missionária sofre uma quebra no seu progresso e atravessa várias vicissitudes com o programa anticlerical dos doutrinadores republicanos" (Ávila de Azevedo, 1963, p.127). A 20 de abril de 1911, foi publicada a Lei da Separação do Estado das Igrejas (Governo..., 1911), que impôs uma rutura entre o Estado e a Igreja, até ali muito cúmplices (Santos, 1969), deixando desse modo espaço para o estabelecimento de outras ordens religiosas.

A 2 de novembro de 1913, essa lei expandiu-se para os territórios africanos, ${ }^{13}$ retirando da responsabilidade das missões católicas a educação dos africanos e transferindo-a para as missões laicas, que viriam então a ser criadas. Essa separação teve consequências na ação evangelizadora em curso naqueles territórios, uma vez que

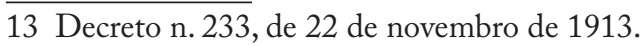




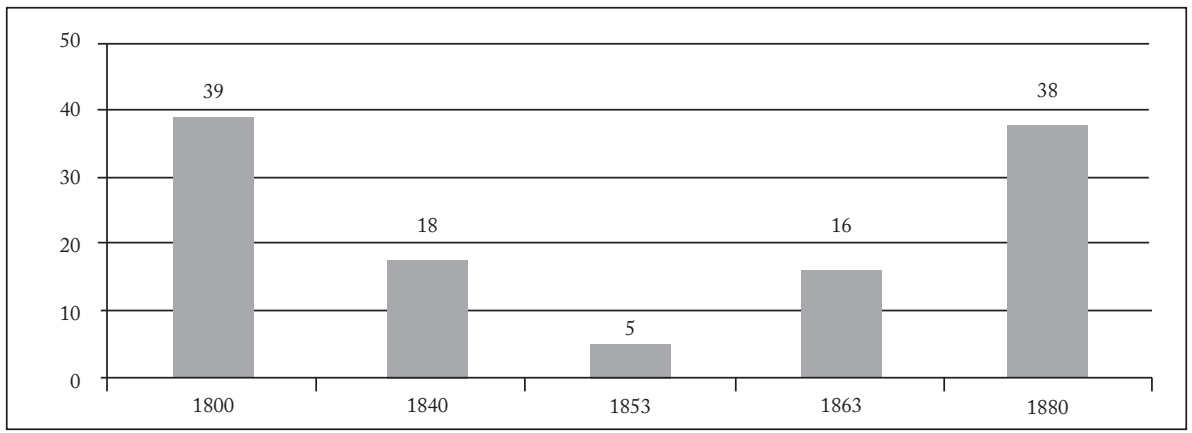

Figura 1 - Número de missionários católicos em Angola (1800-1880).

Fonte: Henderson (1990, p. 36).

Elaboração da autora.

“os padres que não quiseram secularizar-se tiveram que abandonar os seus colégios e missões" (Serrão, 1989, p. 375).

Essa situação alterou-se em 1926, quando João Belo, então ministro das Colónias, promulgou o Estatuto orgânico das missões católicas portuguesas da África e Timor $^{14}$ (conhecido também como o Estatuto Missionário de João Belo), pelo qual atribuiu à Igreja católica a responsabilidade pela educação dos nativos.

As relações entre o Estado português e a Igreja católica foram reforçadas a partir de 1930, com a publicação do Ato Colonial, que no seu artigo 24 estabelecia que:

as missões católicas portuguesas do ultramar, instrumentos de civilização e influência nacional, e os estabelecimentos de formação do pessoal para os serviços delas e do Padroado Português, [terão] possibilidade jurídica e serão protegidos e auxiliados pelo Estado, como instituições de ensino. (Portugal, 1930, p. 1.311)

Essa cumplicidade entre a igreja católica e o Estado colonial português contribuiu para a consolidação e evolução do projeto de construção da nação portuguesa, bem como da política civilizacional ultramarina. Essa renovação de interesses levou posteriormente à assinatura do Acordo Missionário, de 7 de maio de 1940, destinado a "regular mais completamente as relações entre a igreja e o Estado no que diz respeito à vida religiosa no ultramar português" (Acordo..., 1940), estabelecendo no seu artigo 15 que as missões católicas portuguesas poderiam

expandir-se livremente, para exercerem as formas de atividade que lhes são próprias e nomeadamente a de fundar e dirigir escolas para os indígenas e europeus, colégios masculinos e femininos, institutos de ensino elementar, secundário e profissional, seminários, catecumenatos. (idem)

14 Decreto n. 12.485 , de 13 de outubro de 1926. 
O Estado transferiu assim a responsabilidade do "ensino dos indígenas" para essas missões, não deixando, contudo, de o regular e supervisionar (Ávila de Azevedo, 1963, p. 131).

Esse acordo e posteriormente a aprovação do Estatuto do Missionário ${ }^{15}$ no ano seguinte consolidaram a separação da educação, que passou a ser diferenciada: um ensino organizado e destinado aos brancos (europeus e angolanos) e assimilados, e organizado segundo os critérios em vigor na metrópole; e o ensino especialmente destinado aos indígenas, de cariz mais rudimentar, sendo em 1956 designado de Ensino de Adaptação, "orientado para a aquisição de hábitos de trabalho" (idem, p. 130).

A revogação desse acordo em 1961 e a criação do Levar a escola à sanzala: Plano de Ensino primário rural em Angola 1961-62 (Soares, 2002) não diminuíram a influência das missões católicas, tendo as mesmas sido envolvidas diretamente, como parceiras privilegiadas na implementação do plano do Estado, que assumiu a remuneração de todos os professores, mesmo os que estivessem sob a responsabilidade da igreja. Assim, a influência das missões católicas foi aumentando, bem como o número de alunos, sendo que no ano letivo de "1972/73 existiam 1.620 escolas missionárias (católicas) do ensino primário"(Mateus, 1999, p. 31), ensinando milhares de alunos, em zonas rurais e urbanas.

A chegada das missões protestantes, no final do século XIX, significou maiores oportunidades de acesso à educação e à formação religiosa dos africanos (não brancos) (Pélissier; Wheeler, 2011, p. 124). Os primeiros missionários protestantes que chegaram a Angola em 1878 foram enviados pela Sociedade Missionária Baptista de Londres e fixaram-se em São Salvador do Congo (Henderson, 1990, p. 46). Em oposição às missões católicas que se haviam fixado nas zonas costeiras de Luanda e Benguela, as missões protestantes preferiram fixar-se no interior norte de Angola (São Salvador, Uíge, Quibocolo, Bembe, N’Dalatando, Ambrizete etc.), mas rapidamente se expandiram para a zona centro-sul do país (Pélissier; Wheeler, 2011, p. 125).

Como podemos ver no Quadro 2, o número de igrejas protestantes em Angola não parou de crescer nos anos subsequentes a 1878, expandindo-se por todo o território. Seus ideais de defesa dos direitos e deveres dos africanos, bem como de melhoria das suas condições de vida e do "respeito pela dignidade do africano" (Messiant, 1998, p. 253), constituíram uma séria ameaça ao empreendimento colonial, que não viu com bons olhos a a atuação dessas instituições religiosas. Em contrapartida, a superioridade dos recursos financeiros, aliada à utilização das línguas africanas na evangelização e educação dos africanos, ajudou a consolidar a influência destas em Angola e "em 1960 possuíam já mais de 50 escolas primárias e mais de 1.200 escolas rurais (ensino de adaptação)" (Gonçalves, 1960, p. 105).

Muitos dos futuros dirigentes de Angola receberam sua formação básica nessas missões protestantes e posteriormente contaram com o apoio delas para fazerem sua formação superior no exterior, tal como afirma Jonas Savimbi, numa

15 Decreto-lei n. 31.207 , de 5 de abril de 1941. 
Quadro 2 - Primeiras organizações protestantes que se estabeleceram em Angola

\begin{tabular}{|l|l|l|}
\hline Ano & \multicolumn{1}{|c|}{ Instituição } & \multicolumn{1}{|c|}{ Localização* $^{*}$} \\
\hline 1878 & Sociedade Missionária Baptista Inglesa & São Salvador, Congo \\
\hline 1880 & Conselho Americano de Comissários para as Missões Estrangeiras & Bailundo, Benguela e Bié \\
\hline 1882 & Sociedade Missionária Baptista Americana no Estrangeiro & \\
\hline 1884 & Missões Cristãs em muitas Terras & Planalto do Bié \\
\hline 1885 & Igreja Episcopal Metodista & Luanda, Malange, Huambo \\
\hline 1886 & Igreja Unida do Canadá & Bailundo \\
\hline 1889 & Missões Cristãs em muitas Terras & \\
\hline 1890 & Os Irmãos de Plymouth & Bié \\
\hline 1897 & Missão Filafricana & Caluquembe \\
\hline 1897 & Liga Evangélica de Angola & Cabinda \\
\hline 1907 & Aliança Cristã e Missionária & \\
\hline 1914 & Missão Geral da África do Sul & \\
\hline 1924 & Adventistas do Sétimo Dia & Cabinda \\
\hline
\end{tabular}

*Não há informações para as datas em branco no material consultado. A maioria dos arquivos das próprias ordens religiosas perdeu-se durante o intenso período de guerra ou então está vedada ao público.

Fonte: baseado em Pélissier e Wheeler (2011, p. 126) e Gonçalves (1960, p. 27-33).

Elaboração da autora.

entrevista a José Freire Antunes (1996, p. 92), a qual integra a investigação desse autor sobre a Guerra de África (1961-1974):

Os futuros dirigentes nacionalistas de Angola foram quase todos ajudados por elas. Agostinho Neto estudou com uma bolsa da Missão Metodista, Holden Roberto estudou em Kinshasa, com os missionários batistas, também metodistas, eu com os missionários congregacionistas, o Daniel Chipenda também com os congregacionistas.

O apoio das missões protestantes revelou-se assim fundamental na educação dos africanos (não brancos), sobretudo em relação à sua formação superior, "tendo formado mais assimilados que os católicos" (Messiant, 1998, p. 254). A atribuição de bolsas de estudo no exterior permitiu, desse modo, a muitos angolanos terem acesso a um nível de ensino até ali restrito a europeus e a alguns africanos assimilados. Os jovens alunos protestantes viram assim "abrir-se-lhes outras oportunidades para a Europa, para o Brasil ou para a América do Norte" (Lara, 1999, p. 36). Essa atuação dos missionários protestantes não foi bem aceite pelo regime colonial português, que os acusava de "dar cobertura à rebelião em 1961" e de "preparar os seus mais diretos colaboradores africanos para a independência" (Mateus, 1999, p.37). Acusação que, em 1961, conduziu ao encerramento dessas missões e posterior expulsão dos seus missionários.

A proximidade das regiões de intervenção das missões com a República Democrática do Congo, país tornado independente em 1960, levou ao estabelecimento dessas missões naquele país em fuga da guerra nas regiões fronteiriças, posto já ali existir um número elevado delas. De acordo com Henderson (1990, p. 111), 
estima-se que em 1961 " 100.000 [angolanos] tivessem atravessado a fronteira e que no final do ano o número total tivesse atingido os 160.000 ". Esses angolanos aproveitaram o apoio das missões protestantes para darem continuidade a seus estudos, sobretudo secundários, grau com que muitos estudantes chegaram à independência, o que lhes tornou possível o acesso imediato ao ensino superior.

Por serem os estudantes mais graduados que Angola tinha no período pós-independência, muitos foram orientados para funções educativas, tendo ingressado em escolas superiores de educação, constituindo atualmente grande parte do corpo docente da Universidade Agostinho Neto (UAN). As missões protestantes tiveram assim um papel ímpar na formação escolar de populações oriundas de meios rurais em situação de profunda dependência.

\section{EDUCAÇÃO COMO MEIO DE CONSTRUÇÃO DO ESTADO-NAÇÃO (1975-1991)}

Em consequência dessa política educativa seletiva, Angola chegou à independência com uma taxa de analfabetismo na ordem dos $85 \%$, uma das mais elevadas do mundo (PNUD-Angola, 2002, p. 26). Essa situação dramática levou o novo governo a dar prioridade à educação, aplicando nessa área grandes investimentos. A adoção de uma nova ideologia política, tendo em vista a formação do novo cidadão angolano, com uma nova personalidade, moldada nos ideais nacionalistas, conduziu à aprovação de reformas que erradicassem a iliteracia.

A primeira alteração registada, prende-se com a aprovação da lei n. 4, de 9 de dezembro de 1975, que nacionaliza o ensino e cria um Sistema de Ensino Geral, de formação técnica e profissional, assumindo o Estado a responsabilidade de oferecer educação a todos os angolanos. Em 1977 foi publicado o decreto n. 26/1977, que estruturou a política educativa como meio de consolidação da independência nacional e definiu a educação como um direito assente nos princípios $^{16}$ da universalidade, livre acesso e igualdade de oportunidades no acesso à escola e à continuação dos estudos (PNUD-Angola, 2002, p. 26), bem como a sua gratuitidade ${ }^{17}$ no seu sentido mais amplo.

O governo estabeleceu, assim, a educação como principal prioridade política dirigindo para esse setor "grandes investimentos, numa tentativa de ultrapassar os fracassos do regime colonial" (idem, ibidem). Em 1976 iniciaram-se as campanhas de alfabetização por todo o país, em escolas, empresas, fábricas, aldeias rurais, instituições militares, dando continuidade ao trabalho que já era realizado nos acampamentos militares, quando da luta pela independência. $\mathrm{O}$ ensino foi estruturado

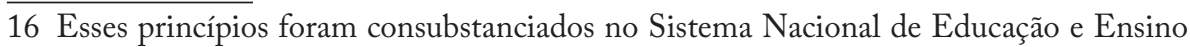
da República Popular de Angola, aprovado em 1977 e implementado a partir de 1978.

17 Inicialmente, nem o estudante nem seu agregado familiar pagavam quaisquer despesas com a educação, e no ensino obrigatório nem o material didático era pago (Angola, 2001a, p. 14). 


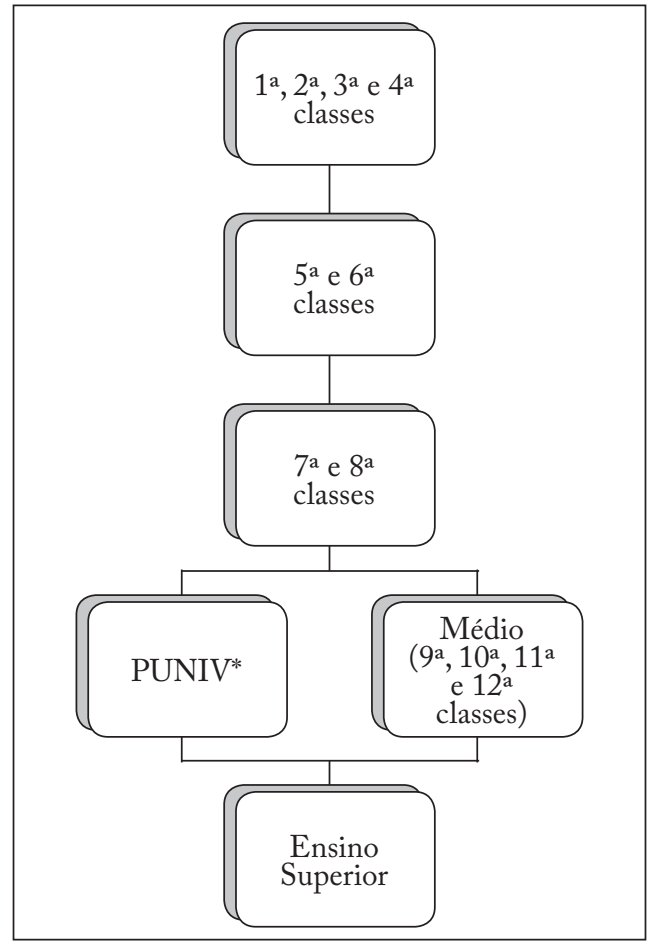

\footnotetext{
Figura 2 - Sistema Educativo da República Popular de Angola (RPA) em 1977.

* Ensino pré-universitário.

Fonte: Baseado em Zau (2009).

Elaboração da autora.
}

em cinco etapas: ensino primário, ensino secundário (I e II nível), ensino médio e universitário.

O ensino primário era composto por quatro anos, antecedidos por um ano de ensino pré-primário, ${ }^{18}$ um conceito que já tinha sido aplicado pela política educativa colonial. Seguiam-se mais quatro anos, dos quais dois do II nível ( $5^{\mathrm{a}}$ e $6^{\mathrm{a}}$ classes) e dois do III nível (7a e $8^{\mathrm{a}}$ classes), que antecediam o curso médio $\left(9^{\mathrm{a}}, 10^{\mathrm{a}}\right.$, $11^{\mathrm{a}}$ e $12^{\mathrm{a}}$ classes) ou o PUNIV (9a $10^{\mathrm{a}}, 11^{\mathrm{a}}$ classes). O ensino médio e o PUNIV tinham como objetivo principal a preparação dos alunos ou para a entrada no ensino superior ou para a vida ativa, dotando-os de formação técnica e prática. Essa estrutura não diferia muito, contudo, da instituída pela política colonial de ensino. Também nesse caso, como vimos, se manteve a educação pré-primária, bem como o uso do termo "classes" para designar cada ano desse nível de ensino. Manteve-se igualmente a preferência pelo ensino técnico, denominado de "ensino médio",

18 O ensino pré-primário antecedia a $1^{\mathrm{a}}$ classe e tinha como objetivo familiarizar a criança com a escola e com a língua portuguesa. 
opção que podia estar relacionada com o fato de se dar continuidade aos programas então ensinados, assim como ao aproveitamento das infraestruturas pré-existentes.

Esse projeto ambicioso do governo angolano deparou-se, porém, com entraves causados pelo início da guerra civil e o consequente mau desempenho da economia, que conduziram a uma cada vez maior dependência do exterior. Assim, o investimento na educação diminuiu gradualmente (substituído que foi pelo investimento em defesa militar) e as medidas que, à partida, se tinham apresentado como revolucionárias, encontraram muitas limitações na sua aplicação prática:

de um total de 512.942 alunos, em 1973, passou a haver 1.026.291 crianças matriculadas na pré-primária e nos quatro primeiros anos de escolaridade [...] Para mais de um milhão de alunos matriculados no ensino primário, havia perto de 25 mil professores heterogeneamente distribuídos pelo país, o que, em condições normais, correspondia a uma média de um professor para cada 41 alunos. Porém, só sete por cento dos docentes ligados ao ensino primário tinha habilitações mínimas para o exercício do magistério. (Zau, 2009, p. 263-264)

Como podemos constatar, o número de alunos inscritos mais que duplicou. No entanto, esse aumento não foi acompanhado pelo igual aumento do número de professores nem pela criação de infraestruturas.

Além disso, a intensificação da guerra civil, "as pesadas destruições de infraestruturas escolares, particularmente nas áreas rurais, o absentismo no seio dos professores, a baixa frequência escolar e as limitações no Orçamento Geral do Estado para fazer face às necessidades de investimento em recursos humanos e infraestruturas" (idem, p. 269) fizeram decrescer o número de matrículas no ensino de base regular nos anos seguintes, tendo passado de 1.736 .552 alunos matriculados no ano letivo de 1980/1981 para 1.220.210 alunos matriculados no ano letivo de 1984/1985.

Para fazer face a esses constrangimentos, tornou-se necessário recorrer a uma adaptação dos meios existentes, bem como à redução do "tempo de permanência do aluno na escola"(Mazula, 1995, p. 164). Desse modo, os horários foram divididos em três turnos: manhã (7:30h às $12: 30 \mathrm{~h})$, tarde $(13: 00 \mathrm{~h}$ às $18: 00 \mathrm{~h})$ e noite $(18: 00 \mathrm{~h}$ às 23:00h), para dar oportunidade a todos, com os mais novos estudando no período da manhã, e os adultos no período da noite. ${ }^{19}$ Procedeu-se igualmente à ocupação de todo o espaço livre para lecionação, desde os espaços no exterior dos estabelecimentos de ensino, a pátios e varandas.

Essa explosão escolar apresentou, contudo, alguns aspetos negativos. Se, por um lado, sua gestão se tornou complexa, por outro, registou-se uma acelerada degradação das infraestruturas, acabando muitas por serem, ao fim de algum tempo, encerradas, tais como bibliotecas, instalações sanitárias, ginásios e refeitórios.

19 Para os alunos do horário noturno, outra condicionante se impôs: os correntes e longos períodos de corte de energia elétrica causados não só pelo aumento do consumo, pela falta de manutenção, como também pela destruição dos postes de abastecimento resultantes do conflito armado. 


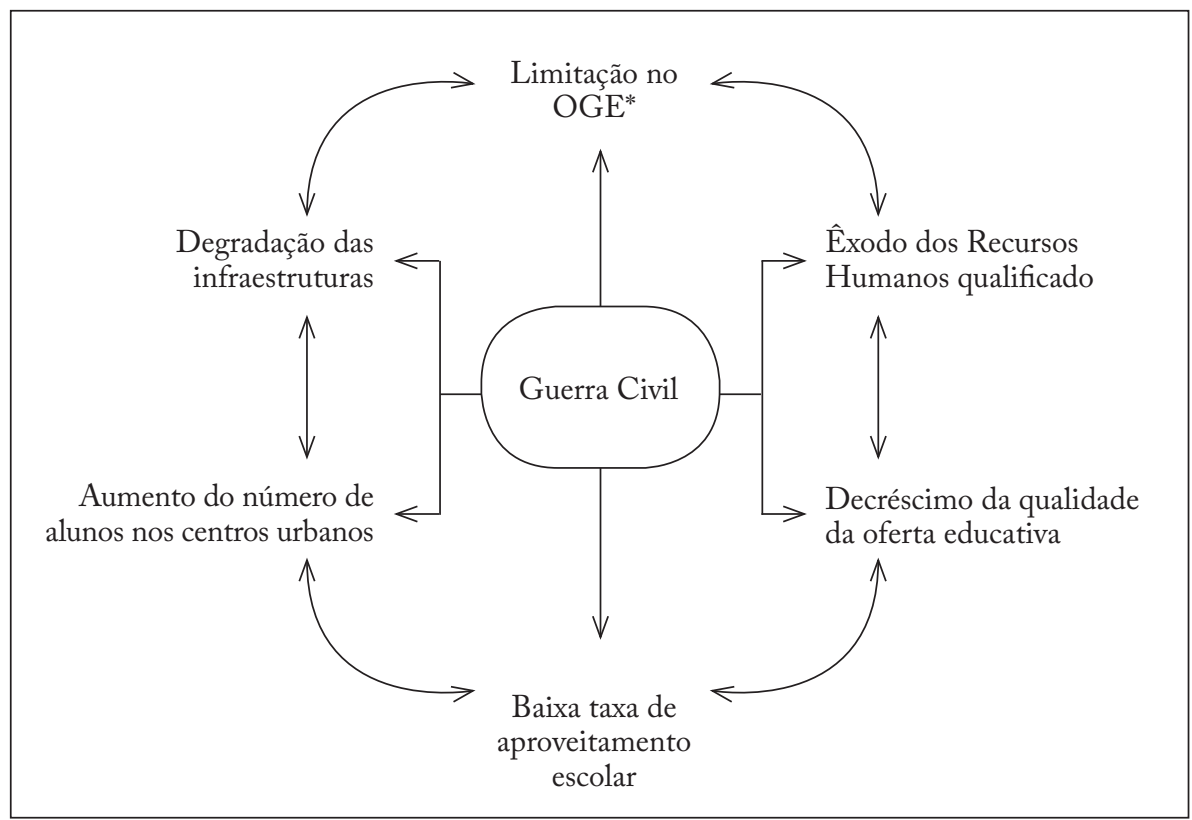

Figura 3 - Consequências da guerra civil para o setor educativo.

* Orçamento Geral do Estado.

Fonte: Baseado nas diversas fontes de informação consultadas.

Elaboração da autora.

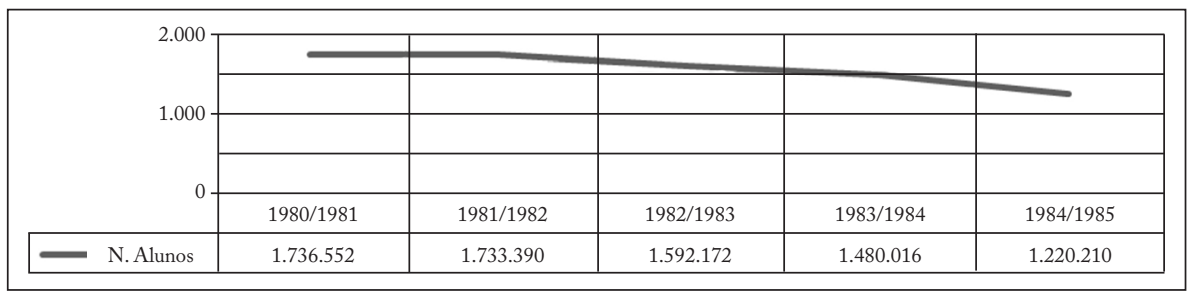

Figura 4 - Número de alunos matriculados no ensino de base regular (1980-1985).

Fonte: baseado em Zau (2009, p. 272).

Elaboração da autora.

Essas dificuldades foram aumentando à medida que a situação económica do país se agravava, o que levou a que se questionasse a qualidade do ensino, sobretudo se tivermos em conta que a maioria dos professores não tinha qualificações para a prática docente. No entanto,

entre uma qualidade que justificava o caráter seletivo e discriminatório do ensino colonial e a quantidade que garante a todos os cidadãos oportunidades iguais de acesso à escola, as populações optam pela última. Preferem ter alunos recebendo aulas ao ar livre à sombra de uma árvore, sentados no chão ou alber- 
gados num alpendre abandonado, a ter poucos alunos selecionados em salas de aula convencionais tecnologicamente bem equipadas. (Mazula, 1995, p. 169)

\section{SEGUNDA REPÚBLICA (1991- ATUALIDADE)}

Com a assinatura dos acordos de Bicesse, ${ }^{20} \mathrm{em} 1991$, e as alterações políticas e económicas que se seguiram, houve, novamente, uma intenção de reestruturar o sistema educativo, extinguindo sobretudo "muito do [seu] teor ideológico-partidário" (Zau, 2009, p. 279). Com o fim do monopólio estatal, registou-se um pouco por todo o país, com especial enfoque para as cidades capitais de província, a abertura de instituições de ensino privado. Os colégios passaram a ser uma alternativa à escola pública que, para além das múltiplas deficiências até então registadas, ainda se deparava com longos períodos de greve dos professores. A política de "ensino gratuito para todos" conheceu, desse modo, o seu término, sendo obrigatório o pagamento de taxas administrativas para a frequência escolar.

O reacendimento do conflito armado em 1992 teve um impacto negativo direto nas zonas urbanas, conduzindo o setor da educação à rutura. Em 1997 "mais de um milhão e meio de crianças estavam fora do sistema escolar" (Angola, 1997, p. 44), as taxas de escolarização eram muito baixas e o analfabetismo apresentava-se, uma vez mais, elevado, bem como os índices de reprovação.

A entrada no novo milénio trouxe novas políticas para o setor da educação em Angola. Depois da Cimeira do Milénio, ${ }^{21}$ Angola iniciou um "processo profundo de revisão das políticas e estratégias que regulavam o setor" (PNUD-Angola, 2002, p. 26), que conduziram à elaboração da Estratégia integrada para a melhoria do sistema de educação (2001-2015) (Angola, 2001a) e à aprovação da Nova Lei de Bases do Sistema de Educação, lei n. 13/2001 (Angola, 2001b). Esses dois documentos estabeleceram as reformas a serem implementadas em todo o sistema educativo. Tendo como meta o ano de 2015, ${ }^{22}$ seriam implementadas em três fases, começando com

20 Acordos de paz assinados entre as duas partes em conflito, nomeadamente o Movimento Popular de Libertação de Angola (MPLA) e a União Nacional para Independência Total de Angola (UNITA). A assinatura dos acordos teve lugar em Bicesse, localidade portuguesa, no dia 30 de maio de 1991. A assinatura do acordo pôs fim à guerra civil em Angola, que já durava desde 1975, data da independência.

21 Reunião da comunidade internacional ocorrida em Nova York, em setembro de 2000, para debater e assinar um compromisso de luta contra a pobreza, a fome e as doenças. Da reunião saiu o documento Declaração do Milênio, assinado por 189 países, no qual constam oito objetivos - conhecidos como Objetivos do Desenvolvimento do Milênio $(\mathrm{ODM})$ - nos quais os países signatários devem esforçar-se por concretizar, de modo que melhore as condições de vida de sua população e comece a traçar o caminho rumo ao desenvolvimento.

22 Indo ao encontro das metas estabelecidas para cumprimento dos ODM, pretende-se aumentar o número de alunos a frequentar o ensino primário de 1,5 milhão para 5 milhões em 2015 (Angola, 2001a). 


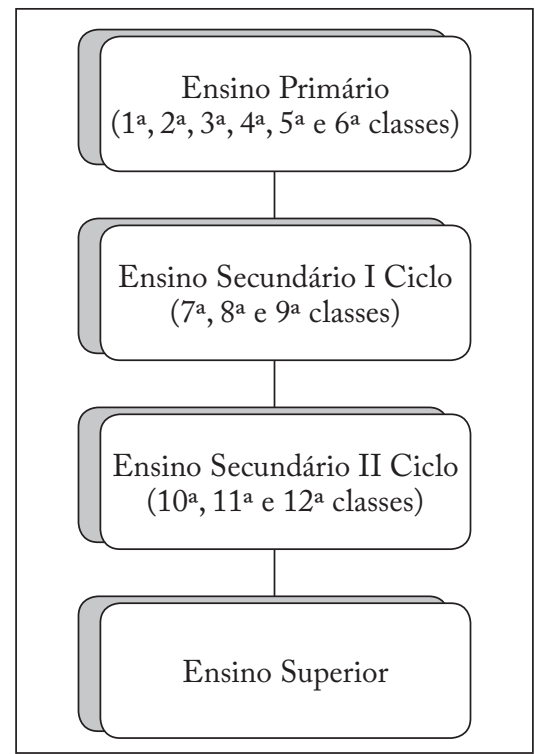

Figura 5 - Sistema educativo da República de Angola. Fonte: Baseado na Nova Lei de Bases do Sistema de Educação, lei n. 13/2001 (Angola, 2001b).

Elaboração da autora.

a fase de emergência (2001-2002) e prosseguindo com a estabilização (2002-2006) e a expansão (2006-2015) (Angola, 2001a; PNUD-Angola, 2002).

A estratégia integrada para a melhoria do sistema de educação (2001-2015) (Angola, 2001a) tem funcionado, até hoje, como um guia de orientação para o governo de Angola, que se comprometeu em cumprir os ODM, nomeadamente, o segundo objetivo: atingir o ensino básico universal. Dando continuidade a esse propósito, a Nova Lei de Bases do Sistema de Educação, lei n. 13/2001 (Angola, 2001b) institucionalizou a democraticidade, a gratuitidade do ensino primário e a língua portuguesa como língua base do sistema de educação, que se estrutura em três níveis: primário, secundário e superior.

O ensino primário ${ }^{23}$ passou a compreender seis anos, integrando o antigo ensino de base do II nível (5 e $6^{\mathrm{a}}$ classes) e proporcionando, desse modo, ao aluno, uma continuidade dos estudos por mais tempo. O ensino primário deve ser frequentado a partir dos seis anos e seu término é previsto para os 11 anos. No entanto, em virtude dos condicionalismos já apontados, a maioria das crianças entra tardiamente no sistema de ensino, acabando também por terminá-lo mais tarde. O IBEP: inquérito sobre o bem-estar da população (Angola, 2010, p. 4), realizado em

23 O ensino pré-primário foi integrado nas creches e jardins de infância porque ocupava instalações e professores destinados ao ensino primário. No entanto, os métodos e práticas pedagógicas aplicados eram semelhantes aos utilizados no ensino primário, não correspondendo assim aos objetivos estabelecidos para essa fase de iniciação. 
2009, mostrou que o ensino primário tinha nesse ano uma taxa de ocupação por crianças entre 12 e 17 anos na ordem dos 58,5\%. Esse fator representa um atraso para a própria criança, uma vez que, na mesma sala, se encontram crianças de idades muito variadas.

O ensino secundário foi estruturado em dois níveis: o I nível (7a, $8^{a}$ e $9^{a}$ classes) e o II nível (10 $11^{\mathrm{a}}$ e $12^{\mathrm{a}}$ classes), seguindo-se o ensino superior.

\section{ENSINO SUPERIOR}

Apesar de a alfabetização e de o ensino primário terem sido apontados como setores educativos prioritários, o ensino superior sofreu igualmente algumas alterações decorrentes da nacionalização do ensino no período pós-independência. Desde logo, a Universidade de Luanda deu origem à Universidade de Angola (1976) e, posteriormente, em 1985, à UAN, em homenagem ao primeiro presidente da República e igualmente primeiro reitor da referida instituição.

O elevado número de angolanos sem instrução explica por que motivo essa universidade não sentiu, nos primeiros anos, os efeitos da explosão escolar registados no I ciclo do ensino básico. Por outro lado, a instabilidade vivida no país no período de transição de poderes refletiu-se no seu funcionamento, que, nos primeiros anos pós-independência, viu mesmo o número de estudantes diminuir.

Assim, entre o ano letivo de 1975/1976 e o ano letivo de 1977/1978, o número de estudantes que frequentavam o ensino superior em Angola baixou de 1.405 para 871 alunos, registando uma diminuição acentuada, se tivermos em conta que no ano letivo anterior à independência (1973/1974) estavam inscritos 2.354 alunos. Somente a partir do ano letivo de 1978/1979 essa universidade começou a se recuperar e a receber mais alunos, não parando de crescer desde então.

Desde o início a UAN se debateu com dificuldades de funcionamento, sobretudo no que respeita aos lugares vagos deixados pelos professores portugueses

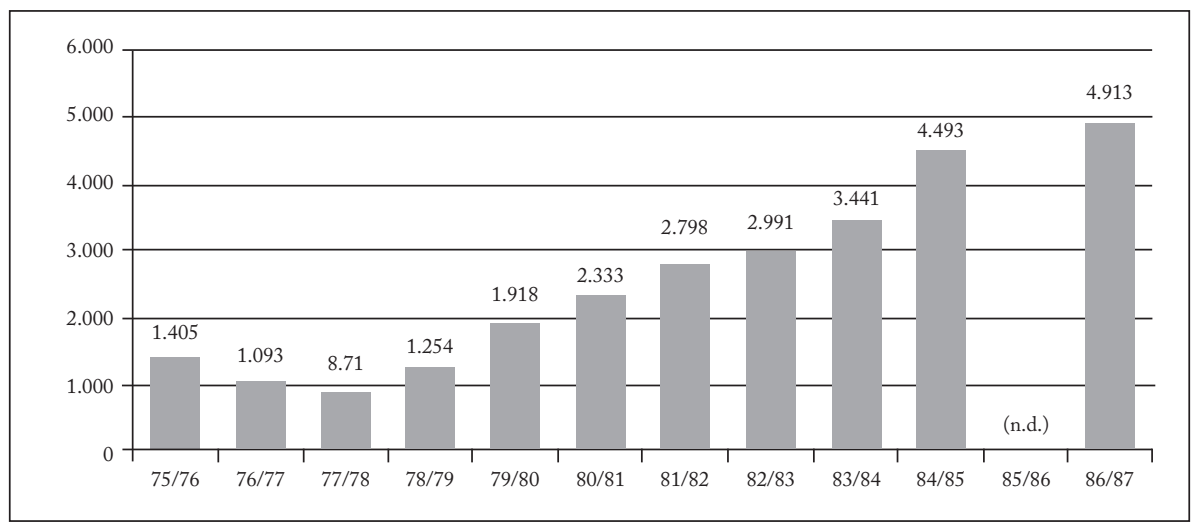

Figura 6 - Evolução do número de estudantes matriculados na UAN.

n.d. = não há dados disponíveis.

Fonte: Gulbenkian (1987, p. 25).

Elaboração da autora. 
que saíram de Angola. Com o passar dos anos, outras debilidades foram surgindo, tais como o aumento galopante do número de alunos, o qual a instituição não conseguia suportar, a falta de instalações e de outras infraestruturas, bem como de material didático. Essas insuficiências são ainda acentuadas pelo fato de os docentes usufruírem de ordenados pouco atrativos e pela:

ausência de políticas públicas de regulação, condicionantes que foram agravando a situação do ensino superior, sendo cada vez menor o número de alunos que conseguia concluir a licenciatura no tempo estipulado, levando cerca de três vezes mais do que o tempo normal de estudos. (Kajibanga, 2000, p. 10-11)

$\mathrm{Na}$ realidade, à medida que o aluno progredia, mais dificuldades enfrentava para dar continuidade aos estudos, uma vez que o número de vagas escasseava por falta de espaço e de professores.

A Estratégia integrada para a melhoria do sistema de educação (Angola,2001a) a que já aludimos, propôs, para o ensino superior, a melhoria da qualidade da formação ministrada, o aumento do número de vagas, a criação de incentivos à investigação, bem como a intensificação da cooperação técnica e científica. No entanto, apenas em 2005 o Ministério da Educação traçou o designado Plano de implementação das linhas mestras para a melhoria da gestão do subsistema de ensino superior (Angola, 2006, p. 6), no qual salientou a intenção do governo em melhorar a qualidade da oferta educativa ${ }^{24}$ bem como a expansão ${ }^{25}$ da rede de instituições de ensino superior, de modo a abranger todo o país, elevando para trezentos mil o número de estudantes a frequentarem as instituições de ensino superior. Para o efeito, reformou a política educativa para esse subsistema de ensino, reestruturou a UAN, criou um sistema de bolsas de estudo internas, ${ }^{26}$ instituiu o Ministério do Ensino Superior, Ciência e Tecnologia (MESCT).

A abertura do país à economia de mercado, a partir de 1991, traduziu-se numa maior exigência nas qualificações das ofertas de emprego. Desse modo, a procura do ensino superior registou nos últimos anos um aumento considerável. Se, por um lado, as habilitações escolares dos angolanos aumentaram, por outro, para os indivíduos do sexo masculino, o fim da guerra civil significou o fim da obrigatoriedade do serviço militar, estando os mesmos abertos à possibilidade de exercerem uma atividade profissional fora desses domínios.

Pela leitura dos dados aqui apresentados, regista-se uma evolução positiva da população estudantil da UAN, tendo passado de 9.129 no ano letivo de 2001/2002 para 46.554 no ano letivo de 2007/2008. Esse aumento da procura de ensino superior, aliado à incapacidade de resposta por parte da universidade pública, bem como a inexistência de ofertas de formação de determinados cursos, proporcionou as condições para a proliferação do ensino superior privado no fim da década de 1990, com destaque para a Universidade Católica de Angola (UCAN), criada em 1999.

24 Taxas de aprovação na ordem de $5 \%$ a $20 \%$.

25 Défice de vagas na ordem de $71 \%$ a $78 \%$.

26 Decreto n. 2/2008, de 28 de fevereiro, do Conselho de Ministros. 


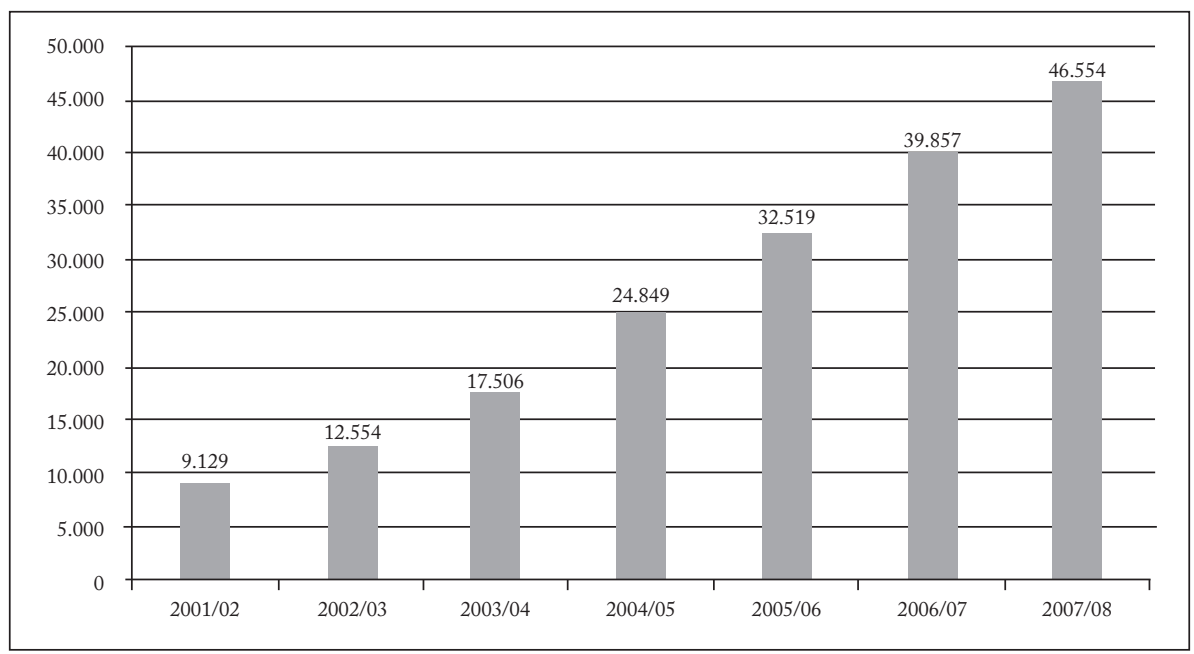

Figura 7 - Evolução da população estudantil da UAN.

Fonte: Baseado em UAN (2008).

Elaboração da autora.

Outras instituições de ensino superior privado surgiram depois da UCAN, tendo sua implementação atingido o apogeu em 2007. Esse aumento e essa diversificação da oferta de ensino superior privado levaram a uma necessidade de reestruturação da política educativa para o ensino superior, tendo como fim sua descentralização. ${ }^{27}$ Desse modo, foram criadas sete regiões académicas (decreto-lei n. 5, de 7 de abril 2009) (Angola, 2009a) de modo a abranger todo o território nacional. Em cada uma das regiões foram criadas instituições de ensino superior para que toda a população tivesse acesso a esse nível de ensino, sem ter que se deslocar, evitando desse modo a rutura nas instituições já existentes, bem como a probabilidade de não retorno às zonas de origem depois de concluída a formação.

Apesar desses esforços consideráveis na formação de recursos humanos, que acompanha o igualmente considerável crescimento económico, constatamos que, trinta e seis anos depois da independência, a situação social de Angola continua muito precária, não tendo as políticas de educação atingido os objetivos inicialmente previstos. De acordo com o Inquérito Integrado sobre o Bem-Estar da Pessoa (IBEP) (Angola, 2010, p. 4), 77,2\% da população frequentam o ensino primário, mas apenas $20,6 \%$ se encontram a frequentar o ensino secundário, uma diferença de percentagem muito significativa e que tem reflexos na continuidade da formação no ensino superior. Segundo dados da Organização das Nações Unidas para a Educação, a Ciência e a Cultura (UNESCO/BREDA) ${ }^{28}$ (2008, p. 46-47), em 2005, apenas 48.184 estudantes se encontravam a frequentar o ensino superior em Angola.

27 Decreto n. 7, de 12 de maio de 2009 (Angola, 2009c).

28 Regional Bureau for Education in Africa (BREDA). 


\section{Quadro 3 - Regiões académicas}

\begin{tabular}{|c|l|l|}
\hline $\begin{array}{c}\text { Região } \\
\text { académica }\end{array}$ & \multicolumn{1}{|c|}{ Províncias } & \multicolumn{1}{c|}{ IES } \\
\hline I & Luanda e Bengo & - UAN \\
\hline II & Benguela e Quanza-Sul & $\begin{array}{l}\text { - Universidade Katyavala Buíla (Benguela) } \\
\text { - Isced (Quanza-Sul) }\end{array}$ \\
\hline III & Cabinda e Zaire & $\begin{array}{l}\text { - Universidade 11 de Novembro (Cabinda) } \\
\text { - Escola Superior Politécnica }\end{array}$ \\
\hline IV & $\begin{array}{l}\text { Lunda-Norte, } \\
\text { Lunda-Sul e Malange }\end{array}$ & $\begin{array}{l}\text { - Universidade Lueji A'Nconde (Lunda-Norte) } \\
\text { - Faculdades de agronomia, medicina e medicina veterinária } \\
\text { (Malange) } \\
\text { - Escola Superior Politécnica (Lunda-Sul) }\end{array}$ \\
\hline V & Huambo, Bié e Moxico & $\begin{array}{l}\text { - Universidade José Eduardo dos Santos (Huambo) } \\
\text { - Escola Superior Politécnica nas províncias do Bié e do } \\
\text { Moxico }\end{array}$ \\
\hline VI & $\begin{array}{l}\text { Huíla, Namibe, } \\
\text { Quando-Cubango e } \\
\text { Cunene }\end{array}$ & $\begin{array}{l}\text { - Universidade Mandume Ya ndemufayo (Huíla) } \\
\text { - Escolas Superior Politécnicas nas províncias do Namibe, } \\
\text { Cunene e Cuando Cubango; }\end{array}$ \\
\hline VII & Uíge e Quanza-Norte & $\begin{array}{l}\text { - Universidade Kimpa Vita (Uíge) } \\
\text { - Escola Superior Politécnica (Quanza-Norte) }\end{array}$ \\
\hline
\end{tabular}

Fonte: Decreto-lei n. 5, de 7 de abril de 2009 (Angola, 2009a).

Elaboração da autora.

Os constrangimentos que Angola atravessou durante o longo período de guerra civil condicionaram, desse modo, o desenvolvimento da política educativa. As recentes reformas introduzidas, quer na educação de base, quer na educação superior, sendo ambiciosas não só quanto à concretização dos ODM, como também quanto à melhoria e sustentabilidade do sistema educativo, não chegaram a ser totalmente consolidadas.

\section{CONCLUSÃO}

Associada aos processos históricos, a evolução da educação em Angola conheceu muitos constrangimentos que condicionaram sua evolução positiva e seu melhor desempenho. Se por um lado a política colonial limitava a progressão escolar dos angolanos (não brancos), criando barreiras, por outro, o processo de transição para se eliminar esses condicionalismos apresentou-se difícil e com muitos sobressaltos. Os objetivos inicialmente traçados pelo governo angolano para serem postos em prática depois da independência - ensino universal, gratuito e obrigatório - depararam-se com sérios entraves, colocando mesmo em questão a sua viabilidade.

O início da guerra civil, o elevado número de alunos, sobretudo nas zonas urbanas, a degradação das infraestruturas, a falta de material escolar, a baixa formação académica e profissional dos professores, os salários pouco atrativos são alguns dos fatores apontados para o decréscimo da qualidade da oferta educativa, bem como para a baixa taxa de aproveitamento escolar ao longo dos últimos 35 anos. 
Em relação ao ensino superior, verificámos que os objetivos que foram traçados para esse nível de ensino não se concretizaram, levando mesmo a um retrocesso no que toca à sua expansão e oferta de formação.

Apesar de todos os condicionalismos e dificuldades de acesso à educação, verifica-se, durante o período de construção do Estado socialista, uma valorização do papel da escola e da educação. Quer esta fosse ministrada "debaixo de uma árvore", quer numa sala de aulas, o importante era todos terem acesso à educação.

Com o fim da guerra em 2002, Angola pôde finalmente implementar as reformas aprovadas em 2001 e dar seguimento aos objetivos que se propôs cumprir (ODM). Nos últimos anos, verificou-se uma melhoria no acesso à educação e à alfabetização, traduzido pelo aumento do número de alunos a frequentar um estabelecimento de ensino. Em relação ao ensino superior, constatou-se um aumento da oferta, tanto pública como privada. Angola parece finalmente estar a cumprir um dos objetivos a que se propôs quando da independência: disponibilizar educação e formação a todos os angolanos. No entanto, o percurso ainda se apresenta longo e as dificuldades a ultrapassar são inúmeras. Mas, a olhar pelos esforços depreendidos e pela vontade dos angolanos em aprenderem, rapidamente esses obstáculos serão ultrapassados.

\section{REFERÊNCIAS}

ACORDO Missionário entre a Santa Sé e a República Portuguesa. 1940. Disponível em: $<$ http://www.vatican.va/roman_curia/secretariat_state/archivio/documents/rc_segst_19400507_missioni-santa-sede-portogallo_po.html >. Acesso em: 9 fev. 2010.

Agência Geral do Ultramar. O ensino no Ultramar. Lisboa: 1966.

Alexandre, Valentim. Origens do colonialismo português moderno (1822-1891). Lisboa: Sá da Costa Editora,1979, v. III.

Velho Brasil novas Áfricas: Portugal e o Império (1808-1975). Porto: Edições Afrontamento, 2000.

Angola. Ministério do Planeamento (MINPLAN). Proposta para uma política de população para Angola. Cadernos da População e Desenvolvimento. Número especial, Luanda, 1997.

. Ministério da Educação de Angola (MED). Conselho de Ministros. Estratégia integrada para a melhoria do sistema de educação (2001-2015). Luanda, 2001a. Disponível em: <http://planipolis.iiep.unesco.org/upload/Angola/Angola_Estrategia_Integrada_ Melhoria.pdf $>$. Acesso em: 3 set. 2014.

. Assembleia Nacional. Lei n. 13, de 31 de dezembro de 2001. Nova Lei de Bases do Sistema de Educação. Diário da República, I Série, 2001b, p. 1.289-1.299.

. Secretaria de Estado do Ensino Superior (SEES). Plano de implementação das

linhas mestras para a melhoria da gestão do subsistema do ensino superior. Luanda, Secretaria de Estado para o Ensino Superior, 2006. 
Conselho de Ministros relativo à Organização das Regiões Académicas. Decreto-lei n. 5, de 7 de abril de 2009. Diário da República, I Série, n. 64, 2009a, p. 1.707-1.708.

Conselho de Ministros relativo ao Programa Executivo do Setor do Ensino Superior. Resolução n. 29, de 15 de abril de 2009. Diário da República, I Série, n. 69, 2009b, p. 1.731-1.745.

Conselho de Ministros Relativo à Criação das Novas Instituições de Ensino Superior Públicas (Regiões Académicas). Decreto n. 7, de 12 de maio de 2009. Diário da República, I Série, n. 87, 2009c, p. 1.855-1.858.

. Instituto Nacional de Estatística de Angola (INE). Boletim de Estatísticas Sociais 2000-2007. Luanda: INE, 2009d.

. IBEP: Inquérito Integrado sobre o Bem-Estar da População - 2008/2009. Luanda: INE, 2010.

Antunes, José Freire. A guerra de África (1961-1974) - Jonas Savimbi: a arte de resistir. Lisboa: Temas e Debates, 1996. v. I, p. 91-102.

Ávila de Azevedo, Rafael. O problema escolar de Angola. Luanda: Edições Casa da Metrópole, 1945.

Política de ensino em África. Lisboa: Ministério do Ultramar, 1958.

1963.

. Relance sobre a educação em África. Lisboa: Junta de Investigações do Ultramar,

Bender, Gerald. Angola sob o dominio português: mito e realidade. Luanda: Editorial Nzila, 2009.

Castelo, Cláudia. Passagens para África: o povoamento de Angola e Moçambique com naturais da metrópole (1920-1974). Porto: Edições Afrontamento, 2007.

Delors, Jacques (Org.). Educação: um tesouro a descobrir. Lisboa: Edições Asa, 1996.

Dias, Alberto Gastão Sousas. O ensino em Angola. Luanda: Delegação do governo de Angola à Primeira Exposição Colonial Portuguesa, 1934.

DiAs, Jill. Uma questão de identidade: respostas intelectuais às transformações económicas no seio da elite crioula da Angola portuguesa entre 1870 e 1930. Revista Internacional de Estudos Africanos, Lisboa: Instituto de Investigação Científica Tropical, n. 1, p. 61-94, 1984.

Duffy, James. Portuguese Africa. Massachusetts: Harvard University Press, 1961.

Enes, António et al. O trabalho dos indígenas e o crédito agrícola. In: Antologia COlOnial PORTUguesa 1: política e administração. Lisboa: Agência Geral das Colónias, 1946 [1899]. p. 25-55.

Gonçalves, António Custódio. Tradição e modernidade na (re)construção de Angola. Porto: Edições Afrontamento, 2003.

Gonçalves, José Júlio. Protestantismo em África: contribuição para o estudo do protestantismo na África portuguesa. Lisboa: Junta de Investigações do Ultramar. v. II, 1960.

Governo Provisório da República Portuguesa. Lei da Separação do Estado das Igrejas. Dia 20 de abril de 1911. Diário do Governo, n. 92, 21 abr. 1911. Disponível em: <http:// 
www.arqnet.pt/portal/portugal/documentos/separacao_das_igrejas.html>.Acesso em: 9 fev. 2010.

GraçA, Pedro Borges. A construção da nação em África (ambivalência cultural de Moçambique). Lisboa: Almedina, 2005.

Guimarães, José Marques. A politica "educativa" do colonialismo português em África: da I República ao Estado Novo (1910-1974). Lisboa: Projedições, 2006.

Gulben kian. Estudo global da Universidade Agostinho Neto. Lisboa: Fundação Calouste Gulbenkian, 1987.

Henderson, Lawrence. A Igreja em Angola. Lisboa: Editorial Além-Mar, 1990.

Kajibanga, Victor. Ensino superior e dimensão cultural de desenvolvimento. Porto: CEAUP, 2000.

LARA, Lúcio. Documentos e comentários para a história do MPLA (até fevereiro de 1961). Lisboa: Publicações Dom Quixote, 1999.

Leal, Cunha. Caligula em Angola. Lisboa: [s.n.], 1924.

LÉonard, Yves. A ideia colonial: olhares cruzados (1890-1930). In: Bethencourt, Francisco; Chaudhuri, Kirti. Nova história da expansão portuguesa: último império e recentramento (1930-1998). Lisboa: Temas \& Debates, 2000. p. 536-553.

Martins, Oliveira. O Brasile as colónias portuguesas. Lisboa: Guimarães \& Cia. Editores, 1953 [1880].

Mateus, Dalila Cabrita. A luta pela independência: a formação das elites fundadoras da Frelimo, MPLA e PAIGC. Lisboa: Editorial Inquérito, 1999.

Matos, Norton. A provincia de Angola. Porto: Edição do Maranus, 1926.

Mazula, Brazão. Educação, cultura e ideologia em Moçambique: 1975-1985. Lisboa: Edições Afrontamento, 1995.

Messiant, Christine. Protestantismes en situation coloniale - Quelles marges? Lusotopie, Paris: Karthala, p. 245-256, 1998.

Mónica, Maria Filomena. Notas para análise do ensino primário durante os primeiros anos do salazarismo. Revista de Análise Social, Lisboa: Universidade de Lisboa, n. 39, X (3०), p. 478-493, 1973.

. Educação e sociedade no Portugal de Salazar (A escola primária salazarista 1926-1939). Lisboa: Editorial Presença, 1978.

Monteiro, Armindo. Da governação de Angola. Lisboa: Agência Geral as Colónias, 1935.

Morin, Edgar. Os sete saberes necessários à educação do futuro. Lisboa: Instituto Piaget, 2002.

Neto, Maria da Conceição. Ideologias, contradições e mistificações da colonização de Angola no século XX. Lusotopie, Paris: Karthala, p. 327-359, 1997.

Paulo, João Carlos. Da "educação colonial portuguesa" ao ensino no Ultramar. In: Bethencourt, Francisco; Chaudhuri, Kirti (Orgs.). História da expansão portuguesa: último império e recentramento (1930-1998). Lisboa: Temas \& Debates, 2000. v. 5, p. 304-333. 
Pélissier, René; Wheeler, Douglas. História de Angola. Lisboa: Tinta da China, 2011. Pimenta, Fernando. Angola: os brancos e a independência.Porto: Edições Afrontamento, 2008.

PNUD - Programa das Nações Unidas para o Desenvolvimento. Relatório do desenvolvimento humano. 2010. Disponível em: <http://www.undp.org/content/undp/ en/home/librarypage/hdr/human_developmentreport2010/>. Acesso: 5 maio 2012.

PNUD-Angola. Os desafios pós-guerra. Luanda: Nações Unidas, 2002.

Portugal. Ato Colonial. Decreto n. 18.570, de 8 de julho de 1930. Diário da República, n. 156, Série I, p. 1.307-1.312, 1930. Disponível em: <https://dre.pt/ pdfgratis/1930/07/15600.pdf>. Acesso em: 18 jan. 2012.

Rodrigues, Eugénia. A geração silenciada: a liga nacional africana e a representação do branco em Angola na década de 30. Porto: Edições Afrontamento, 2003.

SAntos, Eduardo. Religiões de Angola. Lisboa: Junta de Investigação do Ultramar, 1969. Santos, Martins. História do ensino em Angola. Angola: Edição dos Serviços de Educação, 1970.

Serrão, Joaquim Veríssimo. História de Portugal (1910-1926). Lisboa: Verbo, 1989.

SoAres, Amadeu Castilho. Levar a escola à sanzala - Plano de ensino primário rural em Angola (1961-62). Episteme, Lisboa: Universidade Técnica de Lisboa, ano IV, n. 10, 11 e 12, p. 133-164, 2002.

.Universidade em Angola: a sua criação em 1962. Episteme, Lisboa: Universidade Técnica de Lisboa, ano V, n. 13-14, p. 57-69, 2004.

TELo, António José. Economia e império no Portugal contemporâneo. Lisboa: Edições Cosmos, 1994.

UAN - Universidade Agostinho Neto. Livro do finalista 2007/2008. Luanda: UAN, 2008.

Unesco/Breda. Reformes de L'enseignement supérieur en Afrique: eléments de cadrage. Dakar: UnEsco/BredA, 2008. Disponível em : <http://doc.iiep.unesco.org/cgi-bin/ wwwi32.exe/\%5Bin=epidoc1.in\%5D/?t2000=031932/\%28100\%29>. Acesso em: 27 maio 2011.

ZAU, Filipe. Educação em Angola: novos trilhos para o desenvolvimento. Luanda: Movilivros, 2009.

\section{SOBRE A AUTORA}

Ermelinda Liberato é doutora em estudos africanos pelo Instituto Universitário de Lisboa (Portugal). Professora da Universidade Agostinho Neto, Luanda (Angola).

E-mail: ermelinda.liberato@gmail.com

Recebido em junho de 2012 Aprovado em setembro de 2012 
